\title{
Nocardia uniformis nom. rev.
}

\author{
Kamil Isik, Jongsik Chun, ${ }^{2}$ Yung Chil Hah ${ }^{2}$ and Michael Goodfellow'
}

Author for correspondence: Michael Goodfellow. Tel: +44 191222 7706. Fax: +44 1912225228. e-mail: m.goodfellow@ncl.ac.uk

\author{
1 Department of \\ Agricultural and \\ Environmental Science, \\ University of Newcastle, \\ Newcastle upon Tyne NE1 \\ 7RU, UK \\ 2 Department of \\ Microbiology, College of \\ Natural Sciences and \\ Research Center for \\ Molecular Biology, Seoul \\ National University, Seoul \\ 151-742, Republic of Korea
}

\begin{abstract}
A soil isolate representing the putatively novel species 'Nocardia uniformis' was found to have morphological, staining and chemotaxonomic properties consistent with its classification in the genus Nocardia. An almost complete sequence of the 165 rDNA of the strain was determined following cloning and sequencing of the amplified gene. The sequence was aligned with those available for nocardiae and phylogenetic trees were inferred using four treemaking algorithms. The organism was consistently associated with the type strain of Nocardia otitidiscaviarum albeit with a relatively low bootstrap value recorded for neighbour-joining analysis. The strain was also readily separated from representatives of all validly described Nocardia species using a set of phenotypic properties. The genotypic and phenotypic data indicate that the strain should be assigned to the genus Nocardia as a new species. The name proposed for the new species is Nocardia uniformis. The type strain is JCM 3224'.
\end{abstract}

Keywords: Nocardia uniformis nom. rev., polyphasic taxonomy, 16S rDNA sequencing

\section{INTRODUCTION}

The genus Nocardia is well-defined for the first time in its long and tortuous taxonomic history mainly due to the application of chemotaxonomic and molecular systematic methods (Lechevalier, 1976; Goodfellow, 1997). The revised genus encompasses fourteen validly described species which form a monophyletic clade within the evolutionary radiation occupied by mycolicacid-containing actinomycetes, the mycolata (Chun \& Goodfellow, 1995; Friedman et al., 1998; Isik, 1998). Despite improvements in nocardial systematics, the taxonomic position of a number of strains putatively assigned to the genus needs to be resolved.

The name 'Nocardia uniformis' was proposed by Marton \& Szabó (1959) for actinomycetes isolated from the $B_{1}$ horizon of a solonchak-solonetz soil in eastern Hungary. The organism, which was described on the basis of morphological and nutritional properties, was subsequently found to have chemical features consistent with its classification in the genus Nocardia (Mordarska et al., 1972; Yano et al., 1990). Strains of this actinomycete were found to be most closely related to Nocardia otitidiscaviarum in an extensive numerical phenetic survey of the genus Nocardia (Goodfellow,

The GenBank accession number for the $16 \mathrm{~S}$ rDNA sequence of strain JCM $3224^{\top}$ is $Z 46752$.
1971) though the putative type strain was later found to form a distinct single-membered cluster (Yano et al., 1990). 'Nocardia uniformis' was described as a species incertae sedis in the eighth edition of Bergey's Manual of Determinative Bacteriology (McClung, 1974), but was neither mentioned in the corresponding ninth edition (Goodfellow \& Lechevalier, 1989) nor cited in the Approved Lists of Bacterial Names (Skerman et al., 1980).

The aim of the present investigation was to determine the taxonomic relationships of strain JCM $3224^{\mathrm{T}}$ using a combination of genotypic and phenotypic properties. It was clear from the resultant data that the organism merits recognition as a new species of Nocardia, namely Nocardia uniformis nom. rev.

\section{METHODS}

Bacterial strains and cultivation conditions. Strain JCM $3224^{\mathrm{T}}$ was grown in shake flasks containing modified Sauton's broth (Mordarska et al., 1972) for $7 \mathrm{~d}$ at $30^{\circ} \mathrm{C}$; biomass was harvested by centrifugation and washed twice with distilled water. The strain was maintained as glycerol suspensions $(20 \%, \mathrm{v} / \mathrm{v})$ at $-20^{\circ} \mathrm{C}$.

Phenotypic characterization. The test strain was examined for a broad range of phenotypic properties as described in an earlier investigation (Isik et al., 1999). Additional enzymic tests were carried out using an API ZYM kit (bioMérieux) following the instructions of the manufacturer. The inoculated kit was incubated at $37^{\circ} \mathrm{C}$ for $4 \mathrm{~h}$. 


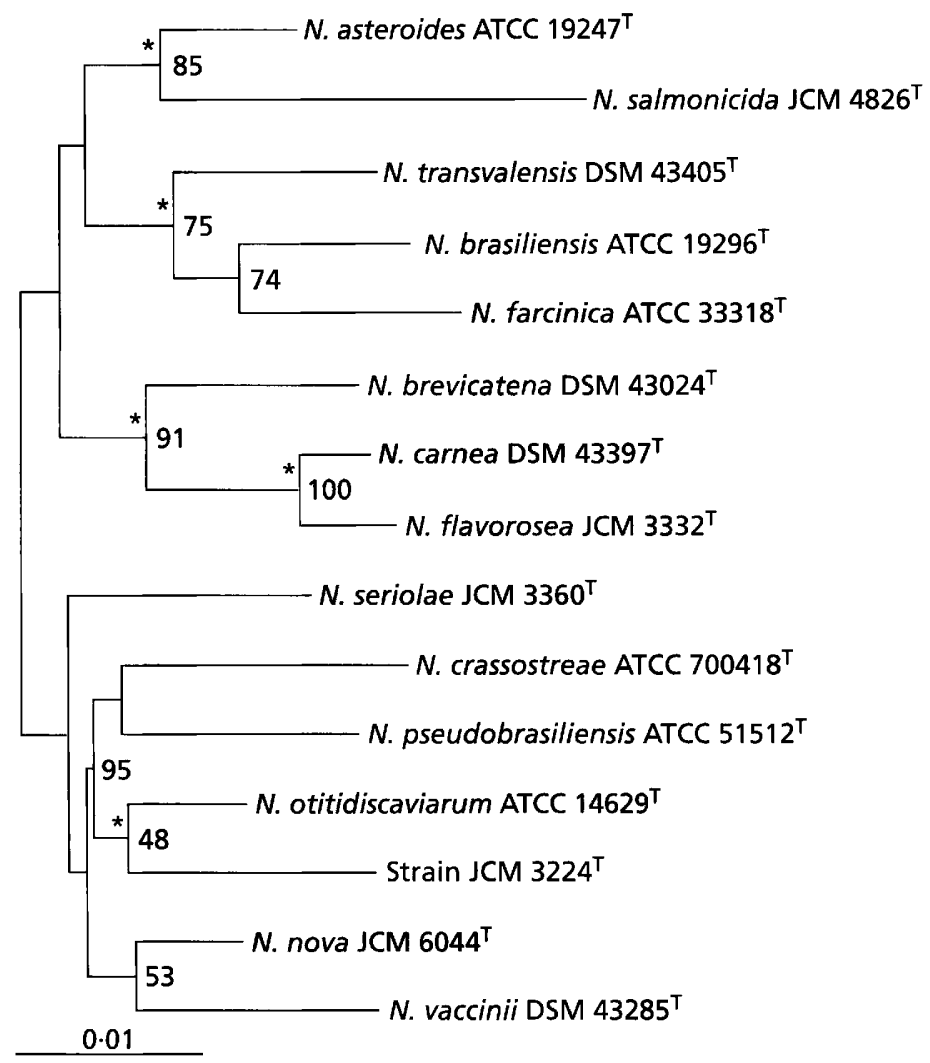

\begin{abstract}
Fig. 1. Unrooted neighbour-joining tree based on 1407 unambiguously aligned nucleotide positions. Asterisks indicate the branches that were also recovered using the Fitch-Margoliash, maximum-likelihood and maximum-parsimony methods. The numbers at the nodes indicate the levels of bootstrap support based on neighbour-joining analyses of 1000 resampled data sets. Scale bar, 0.01 nucleotide substitutions per position.
\end{abstract}

16S rDNA sequencing. Isolation of chromosomal DNA and PCR, cloning and sequencing of the resultant $16 \mathrm{~S}$ rDNA preparation of strain JCM $3224^{\mathrm{T}}$ was carried out using a Taq DyeDeoxy Terminator Cycle Sequencing kit (Applied Biosystems) and an Applied Biosystems 373A DNA sequencer, as described previously (Chun \& Goodfellow, 1995). The 16S rDNA sequence of the test strain was aligned manually against corresponding sequences of representative mycolata strains retrieved from the GenBank and EMBL databases. Evolutionary trees were inferred using the Fitch \& Margoliash (1967), maximum-likelihood (Felsenstein, 1981), maximum-parsimony (Fitch, 1972) and neighbourjoining (Saitou \& Nei, 1987) methods. Evolutionary distance matrices for the neighbour-joining and Fitch-Margoliash methods were generated after Jukes \& Cantor (1969). The unrooted tree topologies were evaluated by bootstrap analyses (Felsenstein, 1985) of the neighbour-joining method based on 1000 resamplings. The phylogenetic analyses were carried out using the PHYLIP package (Felsenstein, 1993).

Chemotaxonomy. The diagnostic isomer of diaminopimelic acid and predominant whole-organism sugars of the test strain were detected using established procedures (Lechevalier \& Lechevalier, 1980). Menaquinones were extracted from freeze-dried biomass $(50 \mathrm{mg})$ and analysed as described previously (Chun \& Goodfellow, 1995).

\section{RESULTS AND DISCUSSION}

An almost complete $16 \mathrm{~S}$ rDNA sequence (1471 nt) was obtained for strain JCM $3224^{\mathrm{T}}$. Comparison of this sequence with corresponding nucleotide sequences of representative mycolata clearly indicated that the organism belongs to the genus Nocardia (data not shown). The test strain contained meso-diaminopimelic acid and major amounts of arabinose and galactose (wall chemotype IV sensu Lechevalier \& Lechevalier, 1970) and predominant amounts of hexahydrogenated menaquinone with eight isoprene units where the end two are cyclized. These results confirm and extend those of earlier studies which indicated that strain JCM $3224^{\mathrm{T}}$ has chemical and morphological properties characteristic of nocardiae (Marton \& Szabó, 1959; Goodfellow, 1971; Mordarska et al., 1972; Yano et al., 1990).

The phylogenetic trees show that strain JCM $3224^{\mathrm{T}}$ is most closely associated with $N$. otitidiscaviarum albeit with a relatively low bootstrap value $(48 \%)$ in the analysis based on the neighbour-joining method (Fig. 1). The $16 \mathrm{~S}$ rDNA sequence similarity between strain JCM $3224^{\mathrm{T}}$ and $N$. otitidiscaviarum NCTC $19349^{\mathrm{T}}$ is $98 \cdot 1 \%$, a value which corresponds to $22 \mathrm{nt}$ differences out of $1351 \mathrm{nt}$ positions. Similarity values around this level have been reported between several validly described Nocardia species, for instance, between $N$. otitidiscaviarum and Nocardia seriolae $(98.0 \%)$ and Nocardia farcinica and Nocardia nova $(98.4 \%$ ) (Chun \& Goodfellow, 1995); these taxa can readily be distinguished using standard phenotypic tests (Goodfellow, 1971; Isik, 1998). Strain JCM $3224^{\mathrm{T}}$ can be distinguished from representatives of all validly described species of Nocardia, including $N$. otitidiscaviarum using a set of phenotypic properties (Table 1).

The genotypic and phenotypic data clearly show that 
Table 1. Phenotypic characters which distinguish Nocardia uniformis strain JCM $3224^{\top}$ from other nocardiae

Strains: 1, Nocardia uniformis JCM 3224 $; 2$, Nocardia asteroides $\mathrm{N} 317^{\mathrm{T}} ; 3$, Nocardia brasiliensis (five strains); 4, Nocardia brevicatena DSM 43024 ${ }^{\mathrm{T}} ; 5$, Nocardia carnea DSM 43397 ${ }^{\mathrm{T}} ; 6$, Nocardia crassostreae (seven strains); 7, Nocardia farcinica (12 strains); 8 , Nocardia flavorosea JCM $3332^{\mathrm{T}}$; 9 , Nocardia nova (three strains); 10, Nocardia otitidiscaviarum (nine strains); 11 , Nocardia pseudobrasiliensis (four strains); 12, Nocardia salmonicida JCM 4826 ${ }^{\mathrm{T}}$; 13 , Nocardia seriolae (four strains); 14, Nocardia transvalensis (four strains); 15, Nocardia vaccinii DSM $43285^{\mathrm{T}}$. Symbols: ,$+>90 \%$ of strains positive;,$- 90 \%$ of strains negative; ND, not determined; T, type strain. Data were taken from the present study and from Chun et al. (1998), Friedman et al. (1998), Isik (1998) and Isik et al. (1999).

\begin{tabular}{|c|c|c|c|c|c|c|c|c|c|c|c|c|c|c|c|}
\hline Character & 1 & 2 & 3 & 4 & 5 & 6 & 7 & 8 & 9 & 10 & 11 & 12 & 13 & 14 & 15 \\
\hline \multicolumn{16}{|l|}{ Biochemical tests: } \\
\hline Aesculin hydrolysis & + & + & + & + & + & + & + & - & + & + & + & + & + & + & + \\
\hline Nitrate reductase & + & + & + & - & + & ND & + & - & + & + & - & + & + & + & + \\
\hline Urea hydrolysis & + & + & + & - & + & - & + & - & + & + & + & + & - & + & + \\
\hline \multicolumn{16}{|l|}{ Decomposition of: } \\
\hline Adenine & - & - & - & - & - & ND & - & - & - & - & + & - & - & - & - \\
\hline Casein & - & - & + & - & - & - & - & - & - & - & + & - & - & - & - \\
\hline Elastin & + & - & + & - & - & ND & - & - & - & - & + & - & - & + & - \\
\hline Hypoxanthine & + & - & + & - & - & - & - & - & - & + & + & - & - & + & - \\
\hline Testosterone & + & + & + & + & + & ND & + & + & + & - & - & + & - & + & - \\
\hline Tyrosine & + & - & + & - & - & - & - & - & - & - & + & + & - & - & - \\
\hline Uric acid & + & - & - & ND & - & ND & - & - & - & + & + & - & - & + & - \\
\hline Xanthine & + & - & - & - & - & - & - & - & - & + & - & - & - & - & - \\
\hline \multicolumn{16}{|l|}{ Growth on sole carbon sources: } \\
\hline $\mathrm{D}(+)$ Mannitol $(1 \%, \mathrm{w} / \mathrm{v})$ & - & + & + & - & + & ND & - & - & + & + & + & + & - & + & + \\
\hline$\alpha-L(-)$ Rhamnose $(1 \%, w / v)$ & - & - & - & + & - & ND & + & - & - & - & - & - & - & + & + \\
\hline$D(+)$ Sorbitol $(1 \%, w / v)$ & - & + & - & - & + & ND & - & - & + & - & + & + & - & + & - \\
\hline Sodium citrate $(0 \cdot 1 \%, \mathrm{w} / \mathrm{v})$ & - & + & + & - & - & - & - & - & - & - & + & + & + & - & - \\
\hline Growth at $45^{\circ} \mathrm{C}$ & - & - & + & - & - & - & + & + & - & + & - & - & - & - & - \\
\hline
\end{tabular}

strain JCM $3224^{\mathrm{T}}$ merits recognition as a distinct species in the genus Nocardia. It is therefore proposed that the organism be classified in the genus Nocardia as Nocardia uniformis nom. rev.

\section{Description of Nocardia uniformis nom. rev.}

Nocardia uniformis (u.ni.for'mis. L. masc. adj. uniformis having only one form, uniform).

The description is based on data derived from earlier studies (Marton \& Szabó, 1959; Goodfellow, 1971). Aerobic, Gram-positive, catalase-positive, acidalcohol-fast, non-motile actinomycete which forms an extensively branched substrate mycelium which fragments in situ into rod-shaped to coccoid elements $(0 \cdot 7-1 \cdot 1 \times 1 \cdot 1 \times 4 \cdot 0 \mu \mathrm{m})$. A yellowish-orange substrate mycelium carries whitish, sparse to abundant, aerial hyphae. Colony elevation is convex to irregular and colony margins are filamentous. Diffusible pigments are not formed. DNA, elastin, guanine, hypoxanthine, RNA, starch, testosterone, Tweens 20 and 80 , Ltyrosine, uric acid and xanthine are degraded, but not adenine, casein, cellulose, chitin, gelatin, keratin or xylan. Aesculin, allantoin, arbutin and urea are hydro- lysed, nitrate is reduced but activity is not shown against hippurate. The organism is oxidase-negative, does not produce $m$ - or $p$-nitrophenoloxidases and is resistant to lysozyme. 2-Naphthyl caprylate, 2naphthyl phosphate (pH 8.5), 2-cystyl-2-naphthylamide, L-leucyl-2-naphthylamide, 2-glutaryl-phenylalanine-2-naphthylamide, naphthol AS-BI phosphate, 2-naphthyl $\alpha$-D-glucopyranoside and 6-bromo-2naphthyl- $\beta$-D-glucopyranoside are cleaved but 2naphthyl myristate, 2-naphthyl phosphate (pH 5.4), Lvalyl-naphthylamide, $\quad N$-benzoyl-DL-arginine-2naphthylamide, 2-naphthyl $\alpha$-L-fucopyranoside, 2naphthyl $\beta$-D-galactopyranoside, 1-naphthyl $N$-acetyl$\beta$-D-glucosaminide and naphthol AS-BI $\beta$-Dglucuronide are not. Acid is formed from arbutin, $\mathrm{D}(-)$ fructose, $\mathrm{D}(+)$ glucose, glycerol and meso-inositol but not from adonitol, amygdalin, $\mathrm{D}(+)$ or $\mathrm{L}(-)$ arabinose, $\mathrm{D}(+)$ cellobiose, dulcitol, ethanol, $\mathrm{D}(+)$ galactose, glycogen, inulin, $\mathrm{L}(+)$ lactose, $\mathrm{D}(+)$ melezitose, $\mathrm{D}(+)$ raffinose, $\alpha$-L-rhamnose, salicin, $\mathrm{D}(+)$ sorbitol, $\mathrm{D}(+)$ sucrose or $\mathrm{D}(+)$ xylose. $\mathrm{D}(+)$ Glucose, meso-inositol, $\mathrm{D}(+)$ mannitol, $\mathrm{D}(+)$ mannose, paraffin, sebacic acid, sodium acetate, sodium n-butyrate, sodium fumarate, sodium hydro- 
gen malate, sodium propionate, sodium pyruvate, sodium succinate and testosterone are used as sole sources of carbon for energy and growth but not adonitol, amygdalin, $\mathrm{D}(+)$ or $\mathrm{L}(-)$ arabinose, $\mathrm{D}(+)$ arabitol, arbutin, $\mathrm{D}(+)$ cellobiose, dulcitol, $\mathrm{D}(-)$ fucose, $\mathrm{D}(+)$ galactose, glycogen, inulin, $\mathrm{L}(+)$ lactose, $\mathrm{D}(+)$ maltose, $\mathrm{D}(+)$ mannitol, $\alpha-\mathrm{D}-$ melibiose, $\mathrm{D}(+)$ melezitose, $\mathrm{D}(+)$ raffinose, $\alpha$-L-rhamnose, $\mathrm{D}(-)$ ribose, salicin, $\mathrm{D}(+)$ sorbitol, $\mathrm{D}(+)$ sucrose, $\mathrm{D}(+)$ trehalose, $\mathrm{D}(+)$ turanose, $\mathrm{D}(+)$ xylose, xylitol, D$\alpha$-alanine, betaine- $\mathrm{HCl}$, benzamide, $m$ - or $p$-hydroxybenzoic acid, $o$-hydroxybenzaldehyde, DL-norleucine, D-mandelic acid, pimelic acid, L-proline, protocatechuic acid, sodium acetate, sodium adipate, sodium benzoate, sodium azelate, sodium citrate, sodium gluconate, sodium hippurate, sodium lactate, sodium malonate, sodium n-octoate, sodium oleate, sodium oxalate, sodium tartrate, sodium valerate, $\mathrm{L}$-threonine, L-tryptophan or L-tyrosine. The organism grows from 14 to $40^{\circ} \mathrm{C}$, from pH 6.0 to 10 and in the presence of crystal violet $(0.00001 \%, \mathrm{w} / \mathrm{v})$, phenyl ethanol $(0 \cdot 1 \%$, $\mathrm{v} / \mathrm{v})$, potassium tellurite $(0.01 \%, \mathrm{w} / \mathrm{v})$ and sodium azide $(0 \cdot 0001 \%, \mathrm{w} / \mathrm{v})$ but not at $10^{\circ} \mathrm{C}, \mathrm{pH} 5 \cdot 0$ or in the presence of crystal violet $(0 \cdot 001 \%, \mathrm{w} / \mathrm{v})$, sodium azide $(0.0002 \%, \mathrm{w} / \mathrm{v})$, sodium chloride $(10 \%, \mathrm{w} / \mathrm{v})$, tetrazolium $(0 \cdot 1 \%, \mathrm{w} / \mathrm{v})$ or thallous acetate $(0.01 \%, \mathrm{w} / \mathrm{v})$. The organism was isolated from a degraded solonchaksolonetz soil collected from the Hortobagy steppe in eastern Hungary. The species description is based on a single strain and hence serves as the type strain description. The type strain is JCM $3224^{\mathrm{T}}$ (= CBS $224.60^{\mathrm{T}}=\mathrm{DSM} 43136^{\mathrm{T}}=\mathrm{IFO} 13702^{\mathrm{T}}=$ NCIB $963^{\mathrm{T}}$ ). Marton \& Szabó (1959) considered the most characteristic features of Nocardia uniformis to be its uniform appearance on a variety of media and its limited carbon utilization pattern.

\section{ACKNOWLEDGEMENTS}

Part of this work was supported through the UK-Korea Actinomycete Research Programme (BBSRC grant R185/ 05688/01), the British Council Academic Link Scheme (Seoul, Korea) and by a Korean Science and Engineering Council (KOSEF) grant to the Research Center for Molecular Microbiology. K.I. was supported by a scholarship from the University of Ondokuz Mayis, Samsun and the Government of Turkey.

\section{REFERENCES}

Chun, J. \& Goodfellow, M. (1995). A phylogenetic analysis of the genus Nocardia with $16 \mathrm{~S}$ rRNA gene sequences. Int $J$ Syst Bacteriol 45, 240-245.

Chun, J., Seong, C.-N., Bae, K. S., Lee, K.-J., Kang, S.-O., Goodfellow, M. \& Hah, Y. C. (1998). Nocardia flavorosea sp. nov. Int J Syst Bacteriol 48, 901-905.

Felsenstein, J. (1981). Evolutionary trees from DNA sequences: a maximum likelihood approach. $J$ Mol Evol 17, 368-376.

Felsenstein, J. (1985). Confidence limits on phylogenies: an approach using the bootstrap. Evolution 39, 783-791.
Felsenstein, J. (1993). PHYLIP (phylogeny inference package), version 3.5c. Department of Genetics, University of Washington, Seattle, WA, USA.

Fitch, W. M. (1972). Towards defining the course of evolution: minimum change for a specific tree topology. Syst Zool 20, 406-416.

Fitch, W. M. \& Margoliash, E. (1967). Construction of phylogenetic trees: a method based on mutation distances as estimated from cytochrome $c$ sequences is of general applicability. Science 155, 279-284.

Friedman, C. S., Beaman, B. L., Chun, J., Goodfellow, M., Gee, A. \& Hedrick, R. P. (1998). Nocardia crassostreae sp. nov., the causal agent of nocardiosis in Pacific oysters. Int J Syst Bacteriol 48, 237-246.

Goodfellow, M. (1971). Numerical taxonomy of some nocardioform bacteria. J Gen Microbiol 69, 33-80.

Goodfellow, M. (1997). Nocardia and related genera. In Topley and Wilson's Microbiology and Microbial Infections, 9th edn. vol. 2, Systematic Bacteriology, pp. 463-489. Edited by A. Balows \& B. I. Duerden. London: Arnold.

Goodfellow, M. \& Lechevalier, M. P. (1989). The genus Nocardia Trevisan 1889, $9^{\mathrm{AL}}$. In Bergey's Manual of Systematic Bacteriology, vol. 4, pp. 2350-2361. Edited by S. T. Williams, M. E. Sharpe \& J. G. Holt. Baltimore: Williams \& Wilkins.

Isik, K. (1998). Systematics of clinically significant nocardiae. $\mathrm{PhD}$ thesis, University of Newcastle upon Tyne.

Isik, K., Chun, J., Hah, Y. C. \& Goodfellow, M. (1999). Nocardia salmonicida nom. rev. Int J Syst Bacteriol 49, 833-837.

Jukes, T. H. \& Cantor, C. R. (1969). Evolution of protein molecules. In Mammalian Protein Metabolism, vol. 3, pp. 21-132. Edited by H. N. Munro. New York: Academic Press.

Lechevalier, M. P. (1976). The taxonomy of the genus Nocardia: some light at the end of the tunnel? In The Biology of the Nocardiae, pp. 1-38. Edited by M. Goodfellow, G. H. Brownell \& J. A. Serrano. London: Academic Press.

Lechevalier, H. A. \& Lechevalier, M. P. (1970). Chemical composition as a criterion in the classification of aerobic actinomycetes. Int $J$ Syst Bacteriol 20, 435-443.

Lechevalier, M. P. \& Lechevalier, H. A. (1980). The chemotaxonomy of actinomycetes. In Actinomycete Taxonomy, Special Publication 6, pp. 227-291. Arlington, VA: Society for Industrial Microbiology.

McClung, N. M. (1974). Family VI. Nocardiaceae Castellani and Chalmers 1919, 1040. In Bergey's Manual of Determinative Bacteriology, 8th edn, pp. 726-746. Edited by R. E. Buchanan \& N. E. Gibbons. Baltimore: Williams \& Wilkins.

Marton, M. \& Szabó, I. (1959). Nocardia uniformis, a new species from solonetz soil. Acta Microbiol Acad Sci Hung 5, 131-134.

Mordarska, H., Mordarski, M. \& Goodfellow, M. (1972). Chemotaxonomic characters and classification of some nocardioform bacteria. $J$ Gen Microbiol 71, 77-86.

Saitou, N. \& Nei, M. (1987). The neighbor-joining method: a new method for reconstructing phylogenetic trees. Mol Biol Evol 4, 406-425.

Skerman, V. B. D., McGowan, V. \& Sneath, P. H. A. (1980). Approved lists of bacterial names. Int $J$ Syst Bacteriol 30, $225-420$

Yano, I., Imaeda, T. \& Tsukamura, M. (1990). Characterization of Nocardia nova. Int J Syst Bacteriol 40, 170-174. 